Two specimens of the large Plesianthropus from Swartkrans have a well-developed sagittal crest ${ }^{15}$, which is not found in the smaller species. Apart from the fact that this must be taken as a sign of a limited brain capacity, it is to be noted that a sagittal crest in the anthropoids depends upon the absolute size of the species. It is absent from the small gibbon, very rare in male chimpanzees, normal in male orangs and practically always present in the male and often in the large female gorillas. That this structure appears among the Australopithecinae under the same conditions is a very important parallel to the anthropoids, and a significant difference from the Hominidae.

Thus the Australopithecinae apparently are a group of the Hominidæ, which most probably did not rise much above the 'anthropoid' level. The reduction of the dentition only affects the face; their increase in brain capacity is slight and depends upon the absolute size of the species; the possession of a sagittal crest in the large specimen parallels the development of the same structure in the anthropoids. It seems that towards the end of the Pliocene period the early Hominidae were separated into several branches-Australopithecinae in Africa, Gigantopithecus (and undescribed forms) in China, Pithecanthropi in Asia - and that only one of them, the Pithecanthropi, by a harmonious reduction of the whole dentition and-this is the most important point-by an exaggerated and accelerated increase of the brain capacity, gave rise to the Hominidae, of which group we are the most human members.

\footnotetext{
${ }^{1}$ Gregory, W. K., and Hellman, M., Ann. Transvaal Mus., 19, 339 (1939).

${ }^{2}$ Robinson, J. T., Amer. J. Phys. Anthrop., 11, 1 (1953).

${ }^{3}$ Broom, R., "Finding the Missing Link", 74 (London, 1950).

" Dart, R. A., Amer. J. Phys. Anthrop., 7, 1 (1949).

5 Zapfe, H., Palaeobiologica, 7, 111 (1939).

- Toerien, M. J., S. Afric. J. Sci., 48, 293 (1952).

von Koenigswald, G. H. R., Rep. Int. Geol. Congr. Great Britain 1948, part IX, 59 (1950).

- del Campana, D., Palaeontologia Italica, 19, 189 (1913).

- Remane, A., Z. f. Anat. u. Entwicklungsgesch., 82, 391 (1927).

${ }^{10}$ Broom, R., and Robinson, J. T., Transvaal Mus. Mem., 6, 1 (1952).

is Clark, W. E. Le Gros, J. Roy. Anthrop. Inst., 80, 37 (1952).

12 Visser, J. B3., Diss. Zurich, 1 (1948).

${ }^{13}$ Marks, P., Madjalah Ilum Alam Untuk Indonesia, 109, 26 (1953).

${ }^{14}$ Broom, R., Robinson, J. T., and Schepers, Transvaal Mus. Mem. 4, 1 (1950).

${ }^{15}$ von Koenigswald, G. H. R., Proc. Kon. Ned. Akad. Wetensch., B, 56, 403 and 427 (1953); 57,85 (1954).
}

\section{DEPARTMENT OF SCIENTIFIC AND INDUSTRIAL RESEARCH}

\section{REPORT FOR THE YEAR 1952-53}

$\mathrm{T}$

THE report of the Department of Scientific and Industrial Research for the year 1952-53* follows the accepted pattern of previous years. Now exceeding three hundred pages, it includes the short report of the Committee of the Privy Council, over Lord Salisbury's signature, and the thirty-eighth annual report of the Advisory Council, signed by Sir Ian Heilbron, together with the usual summary of work carried out by the various research stations and boards and research associations. The appendixes include a thirty-seven page classified list of departmental publications issued during the year and the * Department of Scientiflc and Industrial Research. Report for the
Year 1952-53 (Cmd. 9083). Pp. 315. (London: H.M.S.O., 1954.) 8s. net. usual lists of assessors to the Advisory Council, of members of the research boards of the Department, and of grants for special investigations during the year. With the lists of the Department's establishments and of the research associations, it provides the scientific and industrial world with material for a sound judgment as to the worth of the Department's work, though the average member of Parliament may well be glad of some further guidance from the Parliamentary and Scientific Committee in assessing the value which the nation is getting for an expenditure of $f 5,773,303$ gross during the year ended March 31, 1953.

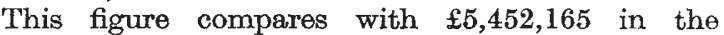
previous year and was reduced to $£ 5,207,455$ by various receipts (mainly by the National Physical Laboratory) for work done for other Government departments or for industry, the net increase on

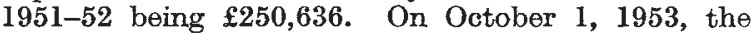
Department employed 4,073 staff of all grades (including 159 part-time), compared with 4,035 (149 part-time) the previous year. Annual grants to research associations, totalling $£ 1,449,635$, with special grants of $£ 16,804$, were as usual the largest single item of expenditure, followed by that of $£ 860,842$ gross, or $£ 546,617$ net, on the National Physical Laboratory. Grants for special researches remained at about the same level, $£ 317,321$, compared with $£ 313,693$ during 1951-52. Most of those listed are spread over a period of years, the largest, apart from the $£ 230,000$ for radio-astronomy at the University of Manchester, being $£ 617,500$ for the construction of a $400-\mathrm{MeV}$. proton synchro-cyclotron and other high-energy equipment for nuclear physics research at the University of Liverpool, $£ 354,700$ for the construction of a $300-\mathrm{MeV}$. electron synchroton and other high-energy equipment for nuclear physics research at the University of Glasgow, 2231,500 for the construction of a $1,000-\mathrm{MeV}$. proton synchrotron and experimental work with a 60 -in. cyclotron at the University of Birmingham, $£ 191,000$ for the construction of a $140-\mathrm{MeV}$. electron synchrotron and other equipment for nuclear physics research at the University of Oxford, and $£ 160,000$ for construction of a $300-400 \mathrm{MeV}$. linear electron accelerator at the University of Cambridge. Besides this, grants amounting to as much as $£ 209,500$ (University of Liverpool) have been made for running expenditure on nuclear physics research. These grants for running expenditure, which total more than $£ 800,000$, extend for five years from August 1, 1952; and by the end of that period the Advisory. Council expects these heavy financial responsibilities for nuclear research in the universities to be terminated so as to bring its net annual resources for general purposes to something of the order of six million pounds.

Grants to students amounted to $£ 265,897$ net, an increase of $£ 14,656$, the number of students in training being 976, compared with 923 during 1951-52, and 413 of these were new. Senior research awards numbered fourteen, seven of which were new, compared with thirteen during 1951-52, and forty-one new grants for special investigations brought the total of such grants to seventy, compared with ninety-one during 1951-52. Of the senior research awards, eight were in physics and three each in chemistry and in engineering ; and of the grants for special investigations, thirty-two were in physics, twenty in chemistry, and six each in biology and in engineering. Chemistry claimed 419 and physics 283 of the grants to students; 79 were in engineering, 
78 in biology, 50 in mathematics and astronomy, 41 in geology and mineralogy, and 26 in metallurgy.

With the exception of building research, expenditure on which decreased by $£ 77,190$ to $£ 420,933$ net, and on the National Physical Laboratory, which showed a net decrease of $£ 12,718$, expenditure on all sections of the work increased, although net expenditure on water pollution research $(£ 61,424)$, fire research (£26,344), hydraulics $(£ 57,676)$, pest infesta. tion $(£ 56,636)$, forest products research $(£ 106,114)$ and on the Geological Survey and Museum (£206,131) was no more than up to 10 per cent higher than during 1951-52. The larger increases of $f 17,051$ on the Chemical Research Laboratory (to $£ 113,574$ net), of $£ 18,538$ on fuel research (to $£ 237,692$ ) and of $£ 19,506$ on road research (to $£ 292,965$ ) fell well within the same order of magnitude. Only the increases of $£ 27,703$ on radio research (to $£ 50,719$ ), of $£ 34,502$ on food investigation (to $£ 220,531$ ) and of $£ 78,733$ on mechanical engineering, represent more significant increases in the scale of operations.

At a total of $£ 346,157$, net expenditure on mechanical engineering ranks fourth in the net outgoings of the Department, and it is now expected that the essential building programme will be completed by 1959 at a cost of about $£ 2$ million. More than $£ 500,000$ has now been expended on the purchase of the site and on buildings at East Kilbride for the Mechanical Engineering Research Organization, and a staff of more than 250 was built up towards the total of 500-700 contemplated in the original proposals for the Organization. The Advisory Council comments on the much more favourable prospects for the expansion of this Organization during the five years commencing April 1, 1954, under the new arrangements announced in November last, particularly in view of the greater flexibility given by the provision that surplus funds due to underspending in any one year may be carried over to subsequent years. Apart from this, provision has been made for small increases of staff and of expenditure on new buildings during the current financial year both at East Kilbride and for the Hydraulics Research Station at Wallingford. At the latter station some three-quarters of the staff originally contemplated have now been recruited, largely within the past year, and by early 1955 some $£ 500,000$ will have been expended on the purchase of the site and provision of buildings. A good beginning has already been made with a substantial programme of research, including experimental studies with models of river estuaries and harbours, theoretical studies of the movement of materials by the action of waves, coast erosion, and the development of instruments. In $a$ study of the changes in the bed of Morecambe Bay, made at the request of the Railway Executive and completed during the year, the Station was able to show that the changes oceur cyclically and that the present deterioration of the channel to Heysham Harbour would not be permanent. Progress has also been made in developing research techniques for the study of coastal erosion ; a pneumatic tide-generator for use in models has been developed, and the Advisory Council was satisfiod on its visit to the Station that important contributions to this branch of civil engineering are already being made there.

The two other establishments of the Department which were formally visited by the Advisory Council during the year were the National Physical Laboratory and the Chemical Research Laboratory, both of which are at Teddington. The former is by far the largest of the establishments and is also the most diverse in its activities, although work is continually being transferred from the Laboratory to form the basis of new institutions. The Advisory Council, emphasizing the dynamic character of the National Physical Laboratory's organization, points out that much of its work is undertaken to serve the basic needs of industry in general and of the public. Its work on the maintenance of increasingly accurate standards of measurement, although only a small part of the Laboratory's work, remains of fundamental importance, and measurements of the speed of light or the development of a new method of producing diffraction gratings are no longer of purely academic interest but of fundamental importance in both science and industry. Theoretical studies and small-scale experiments in wind tunnels by the Aerodynamics Division of the Laboratory are assisting to define the nature of the problems of the behaviour of bodies moving in air at speeds greater than that of sound, which confront the designer of aircraft; and in the theoretical studies of high-speed flight, and in a wide range of other investigations, the Automatic Computing Engine, designed and built at the Laboratory with the help of industry, is assisting to solve mathematical problems of great complexity.

The Advisory Council's visit equally convinced it of the importance of the work of the Chemical Research Laboratory. It was particularly impressed by the work of the new radiochemical laboratory on the analysis and concentration of radioactive materials, and the importance of microbiological work of the Laboratory is also stressed in the report. The work of this Laboratory has recently been reviewed in these columns (Nature, 172, 664 and 832 ; 1953), and no more need here be added than that the Advisory Council directs attention to the economic value of the work on the corrosion of metals and the recovery of valuable constituents from waste materials or low-grade sources.

From the account of the work of the other establishments of the Department, which occupies some eighty-nine pages of the summary of work, compared with a hundred and thirteen devoted to the work of the research associations, only a few examples of the range and importance of the contribution being made to the national welfare and economy can be selected. During the past year the Joint Fire Research Organization has been able for the first time to examine statistics covering a period of five years and thus to examine trends in certain types of hazard, with the result that steps have already been taken to eliminate or mitigate the worst hazards to which some new types of post-war houses appear to be prone. Considerable progress has been made in the study of smouldering in industrial dusts and other materials such as jute sacking and fibre insulating boards, and fresh light has been thrown by a model technique on the importance of ventilation in the development and control of fires. Commenting on the first five years of work of the Organization, the Advisory Council expresses the view that the experiment has been completely satisfactory.

The Building Research Station continued its study of productivity, including an investigation at Norwich of the potential value of a rail-mounted tower crane in house-building, which has led to the development of several special pieces of equipment for handling various building materials and to the design of special equipment, such as turntables, to enable the 
crane to negotiate corners. In collaboration with the Forest Products Research Laboratory, the Station has shown in laboratory tests and in small-scale trials that a zinc oxychloride paint or plaster effectively prevents the spread of dry rot. Work on the use of pulverized fuel-ash for brick-making has been pursued on a larger scale in collaboration with the British Electricity Authority ; and, besides work on prestressed concrete which has established a correlation between behaviour under static and impact loading and on the stiffening effects of walls and floors on structural frameworks, the Station has investigated the soil mechanics of serious breaches in the earth banks of the sea defences in Kent and Essex. The Station has also closely co-operated with the Architects Branch of the Ministry of Education in experimental work on the heating, lighting and acoustics of schools, which has indicated possibilities of economy in fuel by warm-air heating, and a survey of the design and performance of drainage systems is being made with the object of making recommendations for economical and efficient practice.

Under the Food Investigation Organization, wastage surveys have confirmed that the washing of eggs on the farm adversely affects the storage life of the egg. At the Torry Research Station a pilotscale vertical-plate freezer has been designed which may be suitable for installation on existing vessels, and experiments have indicated that fish can be held in ice for at least three days before freezing without detriment to quality. To meet the needs of the Humber area, a new laboratory was opened in December 1952 as an outstation of the Torry Research Station. A mobile refrigerated store has been designed and built which has been used in various producing areas in England and Scotland for precooling strawberries, raspberries and plums immediately after harvest, to improve the keeping qualities, and for storing Cornish broccoli and spring cabbage; and means of reducing the costs of the two main methods of suppressing the sprouting of stored potatoes are being investigated, for both the use of growth-inhibiting vapours, such as amyl alcohol, and cool storage, are still too expensive. Basic investigations include studies of the properties of the proteins of connective tissue and of the fibrous protein, as it exists in tissues, of the lipids, proteins and soluble extractives of fish flesh, of the chemistry of wood smoke and of the chemical substances which are responsible for the browning, caused by certain enzymes, which occurs when some living plant tissues are injured. The volatile substances produced by apples during storage are being identified and estimated, and a survey is being made of the ascorbic acid content of the chief herbage plants.

In the Forest Products Research Laboratory high priority has been given to the production of preservative-treated plywood. New projects in timber mechanics include investigations on the strength of struts of the type used in light constructional work; on the effect of the construction of plywoods on their strength; and on the design, performance and working stresses of plywood components in structures. General biological work on the common furniture beetle, and further work on the production of hardboards from tropical timbers continued, while studies of beech, oak and Corsican pine showed that at a given humidity the Young's moduli decrease linearly with increase of temperature, although at 90 per cent relative humidity there is evidence of a curvilinear relation.
Increased calls for advisory work continued to be made on the Fuel Research Station, which is exploring the possibility of a relation between the rank of a coal and the germanium content as part of a survey of the occurrence of germanium. Work on the production of metallurgical coke by carbonizing blends of coking coals with other coals continued, and also the study of the factors responsible for changes in the flow properties of residual fuel oils during storage. Work has been started on the adsorption of argon at low temperatures on the iron catalysts used for the Fischer-Tropsch synthesis to see if there is any relation between pore structure and catalytic activity. Efficiencies of up to 90 per cent have been obtained in the removal of sulphur dioxide from flue gas in a scrubber containing a carbon packing in which the grid surfaces are thoroughly wetted at low rates of liquor circulation and the liquor is aerated through a ceramic filter-candle; further work was also carried out with three types of combustion chamber intended to permit the use of solid fuel in industrial gasturbines. Work at the Station has shown that emission of smoke from forced-draught or naturaldraught hand-fired steam boilers can be prevented by the correct use of secondary air, and for the naturaldraught types a special fire door has been developed for the purpose.

The publication of maps and memoirs by the Geological Survey has been retarded by the current necessity for concentrating on problems connected with coalfield development, mineral and water resources and hydro-electric schemes; but some progress has been made in acquiring new basic geological data and applying new methods of research. Field work included a survey of the causes and results of erosion in the valleys converging on Lynmouth in North Devon, and the drilling of a borehole on the advice of the Survey averted the necessity for an expensive scheme of piped water supply to Holy Island ; in the search for uranium, field investigations of ore deposits were undertaken by officers of the Atomic Energy Division of the Survey in most of the British Colonies, some Commonwealth countries and other territories overseas. A survey of water resources in areas of Bunter Sandstone in Nottinghamshire showed that, in the northern part of the county, reserves will permit a further daily abstraction of about 19 million gallons, and areas of saline water infiltration in chall areas in Yorkshire and East Lincolnshire have been similarly defined.

In mechanical engineering research the year has been one of consolidation; but the report refers to the work on the fatigue strength of notched and unnotched high-strength aluminium alloys which is nearing completion and to the installation of laboratory equipment for work on materials subjected to high temperature and complex stresses. Experiments on pitot-tubes in water have established that flutter at higher speeds affects the tube coefficient, but can be virtually eliminated by use of a supporting strut with an aerofoil instead of circular section. Two closed-circuit research rigs have been designed for investigating flow conditions in centrifugal and axial flow pumps up to 25 h.p., and a critical analysis of existing formulæ used for scaling-up the performance of model water-turbines has indicated that Reynoldsnumber corrections should be applied to only part of the losses. A comprehensive programme of research on lubrication and wear had particular reference to the operation of bearings at higher speeds and the elucidation of fundamental aspects of the wear 
process. Re-calibration of precision measuring equipment transferred from the National Physical Laboratory was completed during the year, and a new portable instrument for measuring profile errors on large marine gears was completed and used on several sets of gears for the Admiralty. Work on the design and development of the prototype apparatus for torque and vibration measurements on small high-speed precision ball-bearings was nearing completion. The properties and behaviour of materials under hydrostatic pressure were also being investigated, while, besides a survey of literature on heat transfer during 1948-50 which was being published, further surveys are planned, as well as a detailed survey of all data on natural convection from vertical surfa.ces.

The Pest Infestation Laboratory completed its biological studies on the spider beetle, Ptinus tectus, and its investigation of the fauna of dry birds' nests, which indicated that old nests built on or inside houses constitute a frequent point of entry for such pests as the carpet beetle. A detailed investigation of the storage of grain under air-tight conditions was in progress, and recommendations, based on experimental work, for a twice-weekly application of 5 per cent DDT dust gave virtually complete control of emergence of blowflies from refuse when adopted by the borough council concerned. The effect of insecticides and fumigants on the carbohydrate metabolism of insects was being studied, and a modified method of paper chromatography was developed for the micro-analysis of mixtures of pyrethrins and their derivatives.

The main contribution of the Radio Research Organization is in the field of wave-propagation, where its investigations have led to a better understanding of the mechanisms of transmission between transmitter and receiver and of the properties of the medium traversed. Ionospheric investigations have included the study of propagation conditions over routes extending to many thousands of kilometres and hourly measurements of ionospheric conditions at seven observatories distributed over the world, while the data accruing from the study of highfrequency noise during 1945-51 have been reviewed in a special report. The Station is also concerned with the properties of materials of importance in the technique of telecommunications. The new Water Pollution Research Laboratory at Stevenage, Herts, is expected to be ready for occupation by the middle of 1954, when the work at present carried out at Watford, Garston, Birmingham and Coventry will be transferred to the new building. The. Advisory Council stresses the growing importance of the work on water pollution, and instances the anxiety caused by the condition of the Thames Estuary, to the study of which the Laboratory is at present devoting much of its resources. Other work has been concerned with the effects of customary processes of water treatment on the removal from water of small quantities of radioactive substances, particularly those used in medicine and industry, the treatment of sewage by the process of alternating double filtration, the anaerobic fermentation of liquor from the kiering of cotton, the effects of cyanides on the treatment of sewage in percolating filters, and the development of a standard method for assaying the toxicity of industrial wastes to fish. The work of the Intelligence and Information Division, to which special attention was directed by the Advisory Council in last year's report, receives this year a special section in the "Summary of Work", stress being laid on the work on the conservation of raw materials and the development of programmes of research on human factors in industry, production economics and industrial engineering.

New or revised terms of grant were offered to seven research associations during the year, as well as to the Research Committee of the Furniture Development Council, and the British Whiting Federation Research Council, while the Commonwealth Mycological Institute is to receive $£ 1,000$ a year for the five-year period from April 1, 1953, for the maintenance and expansion of its collection of fungi of industrial importance until the appointment of an additional mycologist, and thereafter $£ 2,000$ a year. The British Cast Iron Research Association receives a further block grant of $£ 20,000$ for the period July 1, 1953-June 30, 1954, and an additiona1 $£ 100$ for each $£ 100$ from industry on the same terms as for the previous five years. Its work on the influence of gaseous elements in cast iron continues to increase : a theoretical study of factors influencing the oxygen content has been completed and work commenced on both oxygen and hydrogen. A comprehensive account has been prepared of the effects of composition and structure on electrical resistivity, and progress made in improving methods of sampling and analysis. Negotiations were in progress for the manufacture of the extractor unit specially designed to control respirable dust from pedestal. grinding wheels, and work on the protection of marine propellers from corrosion and also of water mains buried in corrosive soils has reached the development stage.

For the period January 1, 1953-December 31, 1957, the British Ceramic Research Association, which now covers all the activities of the ceramic industry, is to receive a block grant of $£ 30,000$ a year, conditional on $£ 80,000$ from the industry, and an additional $£ 100$ for each $£ 100$ from industry up to a maximum of $£ 20,000$. A major task of the Association continues to be the definition and control of the properties of the raw materials used in the pottery industry, and attempts are being made at the direct determination of the constituent elements in a clay. The principles involved in a satisfactory system of controlling the rheological properties of the slip have been worked out and put into operation in several works, and much attention has been given to the study of chrome-magnesite and magnesitechrome bricks for steel furnaces. In long-term work on the design and operation of a homogeneous extruded column, a device has been developed for controlling the moisture content of the clay by means of a valve operated by the thrust on the screw, and this device has proved satisfactory in works trials. For the British Coal Utilization Research Association a block grant of $\$ 45,000$ a year was made for the period January 1, 1953-December 31, 1957, conditional on $£ 190,000$ from industry, and a further $£ 50$ for each additional $£ 100$ from industry up to a maximum of $£ 30,000$. Early in the year the new laboratories for work on domestic appliances were opened, and here an electrostatic precipitator has been developed through which the whole flow of flue gas can be passed without appreciable drop and which deposits all smoke on light concentric cylinders where it can be weighed. Work on cyclone combustion has aimed at discovering principles of design for a combustion chamber of suitably limited size to operate under pressure with a gas turbine. Investigations on the effects of coal properties on boiler 
performance, using a chain-grate stoker, have been completed, and work on gas producers has endeavoured to ameliorate tar deposition and improve the quality of gas.

The new block grant for the British Gelatine and Glue Research Association for 1953-55 is at the rate of $£ 6,000$ a year, conditional on $£ 8,000$ from industry, with a further $£ 100$ for each $£ 100$ from industry up to a maximum of $£ 4,000$. The Association, the laboratories of which have only been operating during the past three years, has developed a new technique for fractionating gelatin, based on the solubility in aqueous sodium chloride solution of the complex formed between dodecyl sodium sulphate and gelatin, while an instrument has been designed and produced to check the performance of the testing machine used to grade gelatine and glue as gelling agents. The British Hydromechanics Research Association, the laboratory of which at Harlow was only opened in 1951, is concerned with four main field of work: general problems in fluid flow; centrifugal and allied pumps and turbines; positive displacement machinery; and seals and glands. Useful work on the hydraulic transport of solids and on the design of pump suction pumps has already been carried out, and for the period October 1 , 1953-September 30, 1958, the block grant is $£ 9,000$ a year, conditional on $£ 18,000$ from industry, with a further $£ 75$ for each $£ 100$ from industry up to a maximum of $£ 9,000$.

The research programme of the British Scientific Instrument Research Association has been drastically pruned. Marked progress is reported in the work on anti-glare glass for instrument windows, the use of digital machines in optical computing, the thickness measurement of metal sheaths, humiditysensitive ceramic elements and the conditions governing the efficient use of diamond-bonded tools. For the period April 1, 1955-March 31, 1956, the block grant will continue at $£ 35,000$ a year, conditional on $£ 17,500$ from industry, with a further $£ 100$ for each $£ 100$ from industry up to a maximum of $£ 15,000$. The new block grant to the Coal Tar Research Association for the period April 1, 1953March 31,1958 , will also continue at the present rate of $£ 12,000$ a year, but conditional on $£ 45,000$ from industry, with an additional $£ 50$ for each $£ 100$ from industry up to a maximum of $£ 12,000$. Current work has included the study of the chemical and physical nature of tar and pitch, the utilization of pitch and of creosote, and service work on such problems as the corrosion of mild-steel distilling equipment by hot tar and tar oils, or the formation of deposits in tar stills. Studies on the chemical composition of a pitch-coking distillate, the electrophoresis and ultracentrifuging of tars and solutions of pitch were in progress, and the low-temperature non-destructive hydrogenation of tar oils has been extended to the production of tetrahydronaphthalene and transdecahydronaphthalene from crude and refined naphthalene, and the removal of sulphur from anthracene and phenanthrene.

Besides these grants, two special grants were made towards heavy capital expenditure. One of them, not exceeding $£ 100,000$ and conditional on special contributions of $£ 200,000$ from industry, was approved towards the new laboratory at Leatherhead of the British Electrical and Allied Industries Research Association where, besides its main work on the generation of electrical energy, the economical transmission and distribution and the most efficient utilization of such energy and the reliability of equipment, the Association carries out a substantial amount of fundamental research, in which a general theory of electrons in dielectrics has been established so far as concerns the method of approach; and work on the relation between permittivity, loss angle and structure has shown the importance of texture in determining the properties of a dielectric. In rural electrification, good progress is reported in research on the drying of grain, seeds and fodder crops, and promising results were obtained in preliminary work on the destruction of pests in grain by high-frequency electric fields. The second grant, also not exceeding $£ 100,000$ and conditional on not less than $£ 300,000$ from industry, was to the British Coke Research Association towards a full-scale oven plant to test the possibilities of producing satisfactory coke from blends of coal, including those individually unsuitable.

During 1952 there were forty-one research associations, with an income of four million pounds, of which $£ 1 \cdot 3$ millions came from the Department, compared with twenty-one research associations with an income of $£ 480,000$ ( $£ 178,000$ grant) during 1939. Of the work of the remaining associations, no more can be said here than brief comments on four associations. The formation of the Rayon Section of the British Cotton Industry Research Association in 1928 has contributed largely to the ability of the industry to deal with the new man-made fibres, and the Association has contributed a considerable number of successful devices to improve output or conditions. The Hosiery and Allied Trades Research Association has devised a practical means for synchronizing the rate of feed of yarn to hosiery knitting machines, and a method of impregnating chrome leather with rubber latex, devised by the British Leather Manufacturers' Research Association, permits leather to be waterproofed without losing its ability to transmit water vapour. The Printing, Packaging and Allied Trades Research Association has been concerned with developing the techniques for measuring and comparing odour with the object of assessing the possibility of odour contamination from materials used. in making the packing.

The annual report of the Department thus presents a picture of widely varied activities affecting almost every aspect of industry and national welfare. It is a picture, too, of increasing co-operation and of an organization which is intimately interlocked with the national research effort in Great Britain as a whole, whether concerned with defepce, the development of atomic energy or the fundamental research in progress at the universities. The wise direction of this expenditure of effort is a matter of continuing concern to industry and the universities as well as to Parliament, and the present annual report goes far to provide a basis for sound judgment as to the wisdom with which the Department's activities are planned and its objectives selected. The very complexity of the relations disclosed, however, demonstrates the shortsightedness and wastefulness of some of the reductions in expenditure imposed on the Department during recent years. The material supplied in this latest annual report should be used by scientific workers and industrialists to make sure that in future the activities of the Department are guided and modified by views of a sufficiently long range to avoid wasteful repercussions and secure that the nation reaps some return from activities to which it has once been committed. 